\title{
On legal status of Russian companies constructing power facilities abroad
}

\author{
Svetlana Vasilkova* \\ Saint-Petersburg State University of Economics, Sadovaya St., 21, 191023 Saint Petersburg, Russia
}

\begin{abstract}
The article concludes that the legal status of companies engaged in the construction of Russian power facilities abroad is determined precisely by the complex nature of legal regulation, which is carried out simultaneously by various branches and sub-branches of Russian law. Thus, the export of equipment from the Russian Federation and technologies that are used by companies during the construction of Russian power facilities abroad is regulated by the relevant regulatory legal acts of energy legislation and civil legislation, customs, economic, tax and other industries. The article provides examples from energy legislation and other branches of legislation, notes the specifics of regulating the legal status of such companies and the norms that enable them to invest in energy facilities abroad. Some directions for improving legislation in this respect are proposed.
\end{abstract}

\section{Introduction}

The issues of energy development and legal regulation of relations in the energy sector regularly become the subject of attention of both scientists and practitioners.

Special attention should be paid to the issue of the legal status of companies engaged in the construction of Russian energy facilities abroad, since these companies, being the flagships of the Russian presence in the global energy sector, not only ensure the solution of important geopolitical problems, but also master the use of new technologies in foreign markets in a more complex environment. multilayer legal regulation, thereby giving an incentive to the development of appropriate technologies within the country [1]. From the point of view of foreign legislation, their status is determined by the principles and norms in force in the territory of the country in which the corresponding activities for the construction of power facilities are carried out.

However, for the Russian legal space, these companies also remain subject to legal regulation in the part related to the current Russian legislation. Currently, a number of large Russian companies are stepping up their participation in foreign projects in the traditional energy sectors. Russian companies are actively interacting with foreign counterparties, including the construction of large-scale power facilities abroad, thereby laying the foundations for strong interaction between countries both at the global political and economic level, and in the form of technology export, training and advanced training of specialists,

\footnotetext{
*Corresponding author: vasilkova973@mail.ru
} 
development joint educational programs. This confirms the urgency of the issue of highquality legal support of processes occurring in the economy.

Provided that increasingly frequently the construction of Russian power facilities abroad and the activities of Russian companies there become the field of complex geopolitical games, in which rivals can use non-economic political measures against our country, in fact, to conduct the unfair competition in other ways.

\section{Materials and Methods}

The US sanctions against Russia in connection with the construction of the Nord Stream 2 gas pipeline are a prime example of the use of political methods to harm competitors in economic competition in the energy markets. According to analysts, the penalties of the United States of America for the construction of Nord Stream 2 were adopted and came into effect on December 21, 2019. In this regard, Allseas immediately announced that it was stopping all pipeline installation activities. US sanctions against companies that are involved in the construction of the gas pipeline also include a complete ban on crossing borders with the United States. Moreover, all property of corporations located in America is frozen. These measures could affect the assets of Allseas, which is based in Texas, as well as Allseas vessels sailing in the territorial waters of the United States of America.

Additional administrative barriers on the way of foreign investors to the construction of energy facilities in foreign countries can be regional integration associations, which become secondary superstructure structures that can prevent the emergence of such facilities for geopolitical purposes, even against the national interests of their member countries.

It is known, for example, what obstacles to the construction of Russian gas pipelines have been created and are being created by the regulatory bodies of the European Union. According to Forbes, after the commissioning of the Nord Stream 2 route, Gazprom will have the potential to pump 110 billion cubic meters of gas a year from Russia to Germany via 4 strings of the two Nord Streams.

From the southern direction through the Black Sea and Turkey, the company plans to send about 16 billion cubic meters to Europe annually. Also, about the same amount will be able to send to Turkish consumers. The construction of the four-line South Stream with a total capacity of 63 billion cubic meters, which was originally planned, had to be completed when it turned out that, despite the construction started and billions of dollars spent, there would be no permission from the EU regulatory bodies.

\section{Results and Discussion}

Considering the legal status peculiarities of companies conducting their activities on the construction of Russian power facilities abroad, according to Russian national legislation, I would like to note that in this case, the question of whether to include the legal regulation of the construction of such facilities in the subject of legal regulation of energy law is of interest, whether it is recognized as an independent branch of law. Given that this issue in the domestic legal science remains controversial. Either these relations should be the subject of private international law, or even comparative jurisprudence.

There are arguments in favor of each approach, but ultimately it is necessary to keep in mind that the legal system is a complex, developing phenomenon that includes not only branches of law, but also subsystems of the second and third order, complex legal institutions and legal arrays. at the junction of a number of industries and even at the junction of national and international law. In our opinion, the legal status of companies engaged in the 
construction of Russian energy facilities abroad is determined precisely by the complex nature of legal regulation, which is carried out simultaneously by various branches and subbranches of Russian law.

Thus, the export from the Russian Federation of equipment and technologies that are used by companies during the construction of Russian power facilities abroad are regulated by the relevant regulatory legal acts of energy legislation and civil legislation, customs, economic, tax and other industries.

\section{Conclusions}

Russian legislation establishes restrictions that domestic companies must comply with when carrying out their activities for the construction of power facilities abroad, if it involves the export of a certain type of technology and materials.

At the same time, transactions on the transfer of ownership to Russian legal entities that are not included in lists 3 and 5 of Article of the Law on the Use of Atomic Energy, Nuclear Materials and Installations, as well as transactions involving the transfer of ownership of nuclear materials to a foreign state or legal entity, committed incorrectly by Russian legal entities with non-compliance with the requirements of 9 of this article are not valid.

More detailed requirements that Russian exporting companies in the energy sector must comply with are contained in by-laws, including the Regulation on the Export and Import of Nuclear Materials, Equipment, Special Non-nuclear Materials and Related Technologies, approved by the Decree of the Government of the Russian Federation dated 15 December 2000 No. 973 [2], Decree of the President of the Russian Federation dated February 14, 1996 No. 202 "On approval of the List of nuclear materials, equipment, special non-nuclear materials and related technologies subject to export control" [3].

The above examples show that the legal status of companies engaged in the construction of power facilities abroad is regulated by national legislation with any special rules in the case when any restrictions are imposed on export activities in the relevant area, related, for example, to security issues.

In other respects, it can be said that this legal status has no fundamental features in comparison with other companies and is established by the general norms of civil law and energy law.

For example, the current legislation establishes a number of norms that allow the state corporation "Rosatom" to participate in the construction of energy facilities abroad. The company has the right to have a bank account with the Central Bank of the Russian Federation, as well as the ability to open accounts with other credit companies on the territory of the Russian Federation and outside its territory.

However, these norms are rather lengthy, in fact, they include several norms of law related to the powers of the state corporation "Rosatom" in relation to energy facilities being built abroad.

From the point of view of legal technique, these norms are far from perfect. It is rather difficult to single out dispositions and hypotheses of specific norms in them, legal constructions are too complicated and difficult to understand.

Therefore, it is advisable to divide paragraph 37 of Art. 7 of the Law on the State Atomic Energy Corporation "Rosatom" into several points, in this case, the legal status of the company in the field of control over the construction of Russian power facilities abroad will be streamlined. Moreover, paragraph 37 is the last on the list and there is no objective reason not to add paragraphs 38, 39 and so on after it. Some sentences that are too long in terms of legal technique should also be split to optimize perception. 
In particular, we suggest making the appropriate changes to this paragraph and breaking it down into the following sub-paragraphs:

"Article 7. "Powers and functions of the Corporation in the field of state management of the use of atomic energy"

"To achieve the goals established by this Federal Law, the Corporation exercises the following powers and functions in the field of state management of the use of atomic energy:

... 37) conducts in the manner provided by the Corporation, at the request of the developer or its authorized person:

a) The inspection of design documentation of nuclear facilities, the construction of which is carried out outside the territory of the Russian Federation in accordance with international treaties of the Russian Federation and financed with the involvement of funds from the budgets of the budgetary system of the Russian Federation, funds of legal entities created by the Russian Federation, legal entities, the share of the Russian Federation in the authorized (share) capital of which is more than fifty percent.

The inspection is carried out for conformity assessment:

- the conditions of the country's legal system, which the atomic energy obtained from new energy infrastructure will be further used;

- the conditions created on the basis of technical regulations of the Russian Federation;

- the conditions of environmental standards, as well as the sanitary and epidemiological situation;

- the conditions that have been developed within the framework of safety requirements that do not contradict the laws of the states that host the energy infrastructure on their territory;

- the design documentation developed by engineers;

b) The verification of engineering survey results, for the project documentation preparation, for the conformity assessment:

- the conditions of the country's legal system, which the atomic energy obtained from new energy infrastructure will be further used

- the conditions that have been created within the framework of safety requirements that do not contradict the laws of the states that host the energy infrastructure on their territory;

38) based on the results of inspections specified in paragraph 37 of this article, issues the conclusion on the compliance or non-compliance of the specified project documentation and the results of engineering surveys with the specified requirements".

Also, the studied Federal Law establishes some powers of the state corporation "Rosatom" allowing to interact with foreign states, which facilitates participation in the construction of energy facilities abroad. Namely, part 3 of Article 14 states that the company can interact in accordance with the legislation of the Russian Federation with state authorities of foreign states and international organizations, and this list also includes the representation of interests in the Russian Federation in the field of the use of atomic energy in international organizations.

Part 4 of Article 14 states that the company, in accordance with the procedure established by the President of the Russian Federation, can allocate its employee (with an employee of the representative office) for the purpose of the employee's work abroad as part of the consular offices of the Russian Federation, diplomatic, trade missions of the Russian Federation, without the participation of data representatives to the staffing table of these institutions. The budget for the maintenance of employees is formed due to the use by the company of the accounts of the mentioned representative offices and institutions of the Russian Federation.

In general, the legal status of the state corporation "Rosatom" is determined by the norms of civil law. For example, the opportunity to invest in foreign organizations is provided for by Part 2 of Article 15 of this Federal Law, and the general principles of investment for non- 
profit organizations are provided for by the more general rule of Article 71 "State Corporation" of the Federal Law No. 7-FZ of January 12, 1996 "On Non-Profit Organizations". According to clause 32 of this article of this Federal Law, "Investment of temporarily free funds of a state corporation is carried out on the principles of repayment, profitability and liquidity of the assets it acquires (investment objects). The Government of the Russian Federation has the right to establish a list of permitted assets (investment objects), the procedure and conditions for investing temporarily free funds of the state corporation, the procedure and mechanisms for monitoring the investment of these funds, the procedure for concluding transactions for the investment of temporarily free funds of the state corporation, forms of reports on the investment of temporarily free funds state corporation, the procedure for the provision and disclosure of these reports".

In general, it should be said that it is difficult to dispute the importance of creating an effective legal framework for the activities of Russian companies in the construction of Russian energy facilities abroad, their relevance and practical relevance. However, the complexity in the field of legal regulation of the activities of Russian companies abroad in the construction and energy spheres lies in the complex nature of its legal support, as well as in the fact that currently there are no unified international legal provisions (in particular, at the level of a universal convention) in the field of construction of energy facilities.

At the same time, the legal regulation of the activities of Russian campaigns for the construction of energy facilities abroad in Russian legislation can be considered sufficient for its effective implementation, subject to some improvement in terms of legal technique in the presentation of existing legislative norms.

\section{References}

1. I.O. Krasnova, Environmental law, 4 (2019)

2. Collected acts of the Russian Federation, 2000, 52, Section 5153

3. Collected acts of the Russian Federation, 1996, 8, Section 742

4. "Rossiyskaya Gazeta", 14, 24.01.1996

5. M.V. Dakalov, Economic aspects of renewable energy development in EU countries: Thesis for candidate of economic sciences (2015)

6. I.A. Novikov, Transport business of Russia, 12 (2010)

7. K.V. Papenov, A.N. Kazantseva, Entrepreneurial law, 2 (2016)

8. V.F. Popondopulo, Energy law and energy legislation: general characteristic, development trends, Energy and law: Collection (2008)

9. O.A. Supatova, Entrepreneurial law, 3 (2016) 